\title{
MIKROENKAPSULASI KONSENTRAT ASAM LEMAK TAK JENUH DARI MINYAK IKAN PATIN
}

\author{
[Microencapsulation of Unsaturated Fatty Acid Concentrate of Catfish Oil]
}

\author{
Siti Zakiyatul Khamidah ${ }^{1) \star}$, Ema Hastarini ${ }^{2)}$, Dedi Fardiaz ${ }^{3)}$, dan Slamet Budijanto ${ }^{3)}$ \\ 1) Program Studi IImu, Sekolah Pascasarjana, Institut Pertanian Bogor, Bogor \\ 2) Laboratorium Pengolahan, Balai Besar Riset Pengolahan Produk Bioteknologi Kelautan dan Perikanan (BBRPPBKP), Jakarta \\ 3) Departemen Ilmu dan Teknologi Pangan, Fakultas Teknologi Pertanian, Institut Pertanian Bogor, Bogor
}

Diterima 25 Agustus 2018 / Disetujui 2 Oktober 2019

\begin{abstract}
Catfish fillet processing industries produce several wastes, such us belly flap. This part has high fat content that can be a source of essential fatty acids. This research aimed to evaluate the physicochemical characteristics of the unsaturated fatty acids obtained from pangasius fish encapsulated with maltodextrin and sodium caseinate at different combinations. To determine the best combination of maltodextrin and sodium caseinate with ratio 90/10, 80/20, and 70/30, parameters such as emulsion viscosity, product yield, microencapsulation efficiency, encapsulated oil yield, water solubility, morphology and whiteness were measured. Based on the results, maltodextrin and sodium caseinate ratio of 70/30 was the most optimal because it resulted in the highest values in terms of microencapsulation efficiency (63.08\%) and oil microencapsulation yield (24.13\%).
\end{abstract}

Keywords: catfish, unsaturated fatty acid concentrate, microencapsulation, maltodextrin, sodium caseinate

\begin{abstract}
ABSTRAK
Industri pengolahan fillet patin menghasilkan beberapa hasil samping seperti belly flap (daging bawah perut). Bagian ini mengandung banyak lemak yang dapat digunakan sebagai sumber asam lemak esensial. Penelitian ini bertujuan untuk mengevaluasi karakteristik fisikokimia mikrokapsul asam lemak tak jenuh (ALTJ) yang diperoleh dari ikan patin yang dienkapsulasi dengan perbedaan kombinasi maltodekstrin dan natrium kaseinat dengan rasio 90/10, 80/20 dan 70/30. Beberapa parameter telah diukur seperti viskositas emulsi, rendemen mikrokapsul, efisiensi mikroenkapsulasi, rendemen minyak terenkapsulasi, kelarutan dalam air, morfologi dan derajat putih. Berdasarkan hasil penelitian, perbandingan 70/30 (b/b) adalah perbandingan maltodekstrin dan natrium kaseinat yang paling optimal. Hal ini berdasarkan hasil yang tinggi dalam karakter utama, yaitu efisiensi mikroenkapsulasi $(63,08 \%)$ dan rendemen minyak terenkapsulasi $(24,13 \%)$.
\end{abstract}

Kata kunci: ikan patin, konsentrat ALTJ, mikroenkapsulasi, maltodekstrin, natrium kaseinat

\section{PENDAHULUAN}

Ikan patin merupakan ikan air tawar yang hidup di beberapa daerah di Indonesia. Ikan ini memiliki rasa yang sedap, populasi yang tinggi, mudah dibudidayakan sehingga industri fillet patin di Indonesia berkembang pesat. Produksi ikan patin cenderung mengalami kenaikan setiap tahun. Kementrian Kelautan dan Perikanan (KKP) melaporkan bahwa produksi ikan patin pada tahun 2018 mengalami

*Penulis Korespondensi

E-mail: filosofikiya@gmail.com kenaikan produksi dari 245,75 ribu ton menjadi 492 ribu ton dari 2015-2018 dengan kenaikan rata-rata mencapai $31,76 \%$ (KKP, 2018).

Ikan patin berpotensial sebagai sumber minyak ikan. Sebagaimana dinyatakan dalam penelitian Hastarini et al. (2012) yang menunjukkan bahwa kadar lemak bagian-bagian tubuh ikan patin berkisar antara 2,72 hingga $35,32 \%$. Bagian kepala, daging belly flap dan isi perut merupakan bagian yang potensial digunakan sebagai bahan baku pembuatan minyak ikan, yaitu dengan rendemen minyak ikan kasar yang dihasilkan berturut-turut sebesar 9,84; 28,52; dan $20,34 \%$ untuk ikan patin siam. Sedang- 
kan untuk ikan patin jambal yaitu 9,54; 25,60 ; dan $30,05 \%$.

Minyak ikan ini banyak dimanfaatkan untuk sektor industri sebagai sumber asam lemak esensial pada berbagai produk pangan, yaitu asam lemak omega-3 (a-linolenat, eikosa-pentanoat/EPA, dan dokosaheksaenoat/DHA) dan omega-6 (asam linoleat). Akan tetapi, jenis asam lemak ini memiliki kekurangan, seperti mudah teroksidasi jika terpapar oksigen, akibatnya terjadi ketengikan dan umur simpan produk menjadi pendek (Hastarini et al., 2012). Salah satu cara untuk menjaga dan melindungi kestabilan asam lemak tersebut adalah dengan melakukan mikroenkapsulasi (Yuliasari et al., 2016).

Spray drying merupakan teknik mikroenkapsulasi yang telah banyak digunakan untuk produksi secara komersial. Hal ini karena Spray drying bersifat mudah digunakan dan fleksibel dibandingkan dengan teknik mikroenkapsulasi lainnya seperti freeze drying, suspensi rotasi, dehidrasi dingin, dan lainlain. Teknik ini dapat digunakan untuk bahan-bahan yang labil terhadap panas karena bahan akan disalut sedemikian rupa sebelum dikeringkan dengan waktu proses pengeringan yang relatif singkat ( $\mathrm{Li}$ et al., 2011). Sehingga memungkinkan untuk mendapatkan bubuk dengan stabilitas yang baik dan memiliki ukuran partikel yang kecil. Pada dasarnya sifat akhir dari produk mikroenkapsulasi dipengaruhi oleh banyak faktor seperti desain spray dryer, bahan penyalut, pengemulsi, dan keseluruhan tahapan mikroenkapsulasi (Santos et al., 2017). Penelitian mengenai mikroenkapsulasi konsentrat PUFA minyak ikan patin belum pernah dilaporkan, baik dari segi penggunaan teknik spray drying maupun bahan penyalut berupa maltodekstrin dan natrium kaseinat.

Maltodekstrin adalah salah satu jenis penyalut yang sering digunakan dalam spray drying. Maltodekstrin adalah pati modifikasi yang diperoleh dari hidrolisis sebagian dengan asam atau enzim. Bahan ini mengandung senyawa $\alpha$-D-glukosa yang sebagian besar terikat dengan ikatan 1,4-glikosidik dan memiliki nilai dextrose equivalent (DE) kurang dari 20. Bahan penyalut ini memberikan perlindungan yang lebih rendah dibandingkan gum arab, karena maltodekstrin tidak mempunyai sifat lipofilik (Quynh, 2016). Karena itu, pada saat aplikasi teknik spray drying untuk mikroenkapsulasi minyak akan menurunkan retensi minyak dan stabilitas emulsi. Akan tetapi daya tahan minyak yang terenkapsulsi lebih tinggi terhadap oksidasi (Yuliasari et al., 2016). Kemampuan enkapsulasi dari maltodekstrin dapat ditingkatkan dengan mengombinasikan bahan penyalut jenis lain (Yuliasari et al., 2016).

Natrium kaseinat adalah garam kasein yang dibentuk dengan pemberian alkali pada endapan kasein. Jenis alkali yang digunakan pada umumnya yaitu kalsium hidroksida atau sodium pada $\mathrm{pH}$ 6,2-
6,7 dengan suhu $80-90^{\circ} \mathrm{C}$ lalu dilakukan proses spray drying. Bahan penyalut ini tahan suhu tinggi dan larut di atas $\mathrm{pH} 5,5$, memiliki molekul yang acak, dan tidak ada definisi secara pasti untuk struktur kimianya. Pada analisis elektroforesis, terdapat setidaknya 20 macam perbedaan komponen protein di dalam natrium kaseinat. Komponen utama yaitu campuran dari alfa kasein, beta kasein dan kappa kasein (Pralea et al., 2011). Bahan ini dapat membentuk ikatan hidrofobik, elektrostatik, hidrogen sehingga mudah membentuk lapisan film dari larutan encer. Natrium kaseinat juga bersifat ekonomis jika dibandingkan dengan bahan penyalut lain. Akan tetapi bahan ini memiliki kekurangan yaitu kinerjanya terbatas pada viskositas tertentu dan memberikan efek pencoklatan pada produk (Cavallieri et al., 2011).

Pemilihan tween 80 sebagai emulsifier disebabkan oleh sifatnya yang tidak toksik, mudah diperoleh dan ekonomis (Trisnawati dan Cahyaningrum, 2014). Penelitian ini dilaksanakan untuk mengevaluasi pengaruh bahan penyalut terhadap sifat fisikokimia mikrokapsul serta memperoleh formula atau kombinasi terbaik dari keduanya.

\section{BAHAN DAN METODE}

\section{Bahan}

Bahan utama yang digunakan dalam penelitian ini yaitu minyak ikan patin yang diperoleh dari ekstraksi dan pemurnian minyak ikan patin hasil samping industri pengolahan fillet patin (Pangasius sp.) di Karawang. Bahan penyalut yang digunakan adalah maltodekstrin (MD) (Shandong, China) dan natrium kaseinat (National starch) sedangkan bahan pengemulsi yang digunakan adalah tween 80 .

\section{Pembuatan konsentrat asam lemak tak jenuh (ALTJ)}

Pembuatan konsentrat ALTJ mengacu pada metode (Hoiriyah et al., 2016) dengan modifikasi yang disesuaikan. Pembuatan konsentrat ini dibagi ke dalam tiga bagian yaitu hidrolisis asam lemak, kristalisasi asam lemak dengan urea, dan ekstraksi asam lemak.

\section{Hidrolisis asam lemak}

Sebanyak $500 \mathrm{~mL}$ minyak ikan patin murni dicampurkan dengan $50 \mathrm{~mL}$ larutan $\mathrm{NaOH}$ dalam etanol (Larutan $\mathrm{NaOH}$ dibuat dengan cara melarutkan $48 \mathrm{~g} \mathrm{NaOH}$ dan $0,5 \mathrm{~g} \mathrm{Na}_{2}$ EDTA dalam $160 \mathrm{~mL}$ larutan etanol dan ditambah $15 \mathrm{~mL}$ akuades) dan diaduk selama 30 menit pada suhu $60^{\circ} \mathrm{C}$, selanjutnya ditambahkan $200 \mathrm{~mL}$ air dan $2000 \mathrm{~mL}$ heksan. Campuran dikocok dengan kecepatan 300 rpm selama 1 jam. Lapisan yang mengandung bahan tersabunkan ditambahkan dengan $\mathrm{HCl}$ pekat sampai $\mathrm{pH}$ menca- 
pai 1 . Selanjutnya dievaporasi pada suhu $50^{\circ} \mathrm{C}$ hingga pelarut habis, kemudian disimpan untuk pisahkan asam lemak jenuh dari asam lemak tidak jenuh.

\section{Kristalisasi asam lemak dengan urea}

Asam lemak ditambahkan pada larutan urea panas $10 \%$ (suhu $60-65^{\circ} \mathrm{C}$ ) dalam metanol $(\mathrm{b} / \mathrm{v}$ ) dengan diaduk pada kecepatan konstan 300 rpm selama 1 jam. Jumlah urea yang dilarutkan sesuai dengan hasil terbaik yang didapatkan oleh Hoiriyah et al. (2016) yaitu perbandingan urea:asam lemak (2,5:1) dengan lama kristalisasi 24 jam pada suhu 5$6^{\circ} \mathrm{C}$. Kristal yang terbentuk dipisahkan dari larutan induk dengan penyaringan. Asam lemak dalam filtrat selanjutnya diekstraksi.

\section{Ekstraksi asam lemak}

Setiap $3 \mathrm{~mL}$ filtrat, ditambahkan $1 \mathrm{~mL}$-heksan dan $1 \mathrm{~mL} \mathrm{HCl}$ pekat. Campuran diaduk selama 1 jam, kemudian didiamkan sampai terbentuk dua lapisan, lapisan atas diambil dan dievaporasi lagi pada suhu $30^{\circ} \mathrm{C} 100 \mathrm{rpm}$, kemudian disentrifus pada kecepatan 7500 rpm selama 20 menit untuk benarbenar mendapatkan hasil ALTJ yang jernih.

\section{Mikroenkapsulasi konsentrat ALTJ (Modifikasi Yuliasari et al., 2016)}

Mikroenkapsulasi konsentrat ALTJ dilakukan berdasarkan modifikasi dari metode Yuliasari et al. (2016) yang menitikberatkan pada perbandingan jumlah bahan penyalut yang digunakan. Tahapan pertama yaitu persiapan pembuatan emulsi antara konsentrat ALTJ dan bahan penyalut dengan perbandingan bahan penyalut (maltodekstrin/natrium kaseinat) 90/10, 80/20, 70/30 (b/b). Formula mikroenkapsulasi konsentrat ALTJ ikan patin dapat dilihat pada Tabel 1.

Jumlah akuades yang digunakan adalah 2,5 kali jumlah (konsentrat ALTJ+penyalut), sedangkan jumlah tween 80 (polyoxyethylene sorbitan monooleate) yang digunakan adalah 3\% dari (konsentrat ALTJ+penyalut+akuades). Selanjutnya emulsi diukur viskositasnya lalu dihomogenisasi menggunakan homogenizer (Ultra-Turrax, Armfield USA) dengan kecepatan $11000 \mathrm{rpm}$ selama 5 menit. Selanjutnya masing-masing sampel dikeringkan dengan alat spray dryer (Buchi 190, Jerman) dengan suhu inlet $180^{\circ} \mathrm{C}$, suhu outlet $100^{\circ} \mathrm{C}$ dan laju alir $10 \mathrm{~mL} /$ menit.

\section{Viskositas emulsi (Hastarini et al., 2012)}

Sampel emulsi dimasukkan ke dalam gelas ukur $300 \mathrm{~mL}$ kemudian diukur viskositasnya dengan menggunakan viscometer digital Brookfield (Middleboro, USA) dengan kecepatan $30 \mathrm{rpm}$ dan spindel 1 untuk perbandingan 90/10 dan 80/20 sedangkan spindel 2 untuk perbandingan 70/30. Kemudian nilai viskositas muncul di layar. Satuan yang digunakan adalah centi Poise (cP).

\section{Rendemen produk (Quynh et al., 2016)}

Rendemen produk (RP) merupakan produk hasil keseluruhan mikroenkapsulasi yang dikalkulasi dari massa produk mikrokapsul dari total padatan (bahan pengapsul, bahan inti dan emulsifier) lalu dihitung dalam persen, rendemen produk dihitung dengan rumus sebagai berikut.

$$
\mathrm{RP}(\%)=\frac{\text { bobot mikrokapsul }(\mathrm{g})}{\text { bobot total bahan padatan }(\mathrm{g})} \times 100 \ldots \ldots \ldots
$$

Minyak total (MT), minyak tidak terkapsul (MTT) dan efisiensi mikroenkapsulasi (EM) (Carneiro et al., 2013)

Minyak total (MT) disebut juga dengan kadar lemak total. Parameter ini menunjukan persentase minyak yang ada dalam mikrokapsul. Minyak tidak terkapsul (MTT) merupakan persentase minyak yang menempel pada dinding mikrokapsul. Kedua parameter ini berpengaruh pada nilai efisiensi mikroenkapsulasi (EM) (Botrel et al., 2014). Efisiensi mikroenkapsulasi dihitung berdasarkan minyak tidak terkapsul dan minyak total. Penentuan minyak tidak terkapsul berdasarkan metode Carneiro et al. (2013), yaitu $1 \mathrm{~g}$ mikrokapsul dimasukkan ke dalam gelas beker dan ditambahkan $20 \mathrm{~mL}$ heksana (Meck, Germany), kemudian dikocok dengan tangan untuk mengekstrak minyak yang berada pada permukaan mikrokapsul. Setelah itu, dilakukan penyaring vakum menggunakan kertas saring Whatman no 42 (Merck, Germany). Sisa mikrokapsul yang tertinggal diekstrak dengan $20 \mathrm{~mL}$ heksana dan disaring kembali hingga tiga kali. Ekstrak yang diperoleh didestilasi menggunakan soxhlet (Gerhardt, UK), sisa pelarutnya diuapkan menggunakan oven hingga beratnya konstan. Setelah itu didinginkan dalam desikator dan ditimbang.

Jumlah minyak total ditentukan menggunakan metode Hastarini et al. (2012). Dua gram mikrokapsul dibungkus dengan kertas saring, diekstraksi dengan pelarut heksana selama 6 jam kemudian didistilasi. Sisa pelarut diuapkan dengan oven hingga beratnya konstan. Minyak total dikalkulasi berdasarkan selisih berat labu kosong dan labu yang berisi minyak hasil ekstraksi. Berikut adalah persamaan untuk menghitung efisiensi mikroenkapsulasi:

$\operatorname{EM}(\%)=$

minyak total-minyak tidak terkapsul minyak total $\times 100$ 
Tabel 1. Formula pembuatan emulsi untuk mikroenkapsulasi konsentrat ALTJ

\begin{tabular}{cccccc}
\hline Rasio MD/NK & Konsentrat ALTJ $(\mathrm{g})$ & Maltodextrin $(\mathrm{g})$ & Natrium Kaseinat $(\mathrm{g})$ & Akuades $(\mathrm{g})$ & Tween $(\mathrm{g})$ \\
\hline $90 / 10$ & 15 & 81 & 9 & 262,50 & 11,025 \\
$80 / 20$ & 15 & 72 & 18 & 262,50 & 11,025 \\
$70 / 30$ & 15 & 63 & 27 & 262,50 & 11,025 \\
\hline
\end{tabular}

Rendemen minyak terenkapsulasi (RMT) (Quynh et al., 2016)

Rendemen minyak terenkapsulasi (RMT) ini digunakan untuk menghitung jumlah minyak konsentrat yang terbuang (loss) selama proses mikroenkapsulasi. Baik pada tahap emulsifikasi maupun spray drying. Parameter RMT dihitiung berdasarkan pada rasio antara bobot minyak yang terenkapsulasi dengan bobot minyak awal yang digunakan, lalu dihitung dalam persen. Berikut adalah perhitungan formulanya.

$\operatorname{RMT}(\%)=$

bobot minyak dalam mikrokapsul bobot minyak awal

\section{Kelarutan mikrokapsul dalam air (Yuliasari et al., 2016)}

Kelarutan ditentukan mengacu pada Yuliasari et al. (2016). Satu gram sampel mikrokapsul (a), ditambahkan $100 \mathrm{~mL}$ akuades kemudian menggunakan penyaring vakum. Kering kertas saring dikeringkan terlebih dahulu pada suhu $105^{\circ} \mathrm{C}$ sekitar 30 menit sebelum digunakan lalu ditimbang (b). Kertas saring beserta residu bahan dikeringkan kembali dalam oven (Contherm, NZ) pada suhu $105^{\circ} \mathrm{C}$ kurang lebih tiga jam hingga beratnya konstan (c).

Kelarutan $(\%)=\left(1-\frac{c-b}{\frac{100-\% k a}{100}}\right) \times 100$.

\section{Analisis morfologi (Yuliasari et al., 2016)}

Analisis morfologi dilakukan menggunakan scanning electron microscope (SEM) (JEOL JCM 6000 plus, USA). Preparasi sampel menggunakan specimen holder dan dilapisi emas. Analisis ini menggunakan perbesaran 5000 kali dan tegangan $20 \mathrm{kV}$ dan dilakukan secara komputasi. Hasil analisis yang diperoleh adalah berupa tampilan partikel dalam bentuk gambar tiga dimensi menurut perbesaran dan skala tertentu.

\section{Analisis statistik (Yuslinawati, 2014)}

Penelitian ini menggunakan rancangan acak lengkap (RAL) sebagai rancangan percobaan. Variabel yang dimasukan pada pembuatan emulsi dan mikrokapsul adalah kombinasi maltodekstrin dan natrium kaseinat dengan taraf perlakuan yaitu 90/10, 80/20, dan 70/30. Perbedaan nilai mean dianalisis dengan analysis of variance (ANOVA) kemudian di- uji dengan Duncan Multiple Range Test (DMRT) menggunakan software IBM SPSS Statistics $22(\alpha=$ $0,05)$.

\section{HASIL DAN PEMBAHASAN}

\section{Viskositas dan rendemen mikrokapsul}

Viskositas merupakan parameter ukuran kekentalan fluida, dalam hal ini yaitu berupa emulsi. Ukuran viskositas sangat terkait dengan gesekan di dalam fluida. Semakin tinggi nilai viskositas suatu fluida maka alirannya semakin terhambat. Viskositas emulsi kerap dipengaruhi oleh kandungan zat yang ada di dalam emulsi.

Viskositas emulsi berpengaruh terhadap rendemen mikrokapsul (RP) yang dihasilkan (Gambar 1). Nilai RP dipengaruhi oleh konsentrasi maltodekstrin dan natrium kaseinat dalam emulsi. Tingginya konsentrasi maltodekstrin akan meningkatkan nilai RP. Sebaliknya peningkatan natrium kaseinat dalam campuran emulsi, maka akan terjadi peningkatan viskositas emulsi, sehingga secara tidak langsung nilai RP nya akan semakin rendah. Nilai RP pada perbandingan MD/NK 90/10 mencapai 39,89\%. Selanjutnya terjadi penurunan yang signifikan pada $80 / 20(24,51 \%)$ dan kembali mengalami peningkatan pada perbandingan $70 / 30$ yaitu $33,07 \%$. Secara teori, hubungan antara viskositas emulsi dengan rendemen produk adalah berbanding terbalik. Adanya penurunan drastis nilai RP pada $80 / 20$ diduga karena adanya loss weight selama proses spray drying. Faktor pengeringan yang kurang sempurna menyebabkan bubuk mikrokapsul memiliki kadar air tinggi dan menempel pada tabung inlet. Sehingga mikrokapsul yang tertampung di tabung outlet menjadi sedikit dan rendemennya menurun. Penelitian ini juga sejalan dengan Quynh et al. (2016) yang meneliti mikroenkapsulasi gac oil dengan berbagai kombinasi penyalut maltodekstrin dan natrium kaseinat. Hasil penelitianya menyebutkan bahwa peningkatan rasio maltodekstrin/natrium kaseinat dari $0,2 / 1$ hingga 0,6/1 akan meningkatkan rendemen produk dari 76,87 hingga $92,46 \%$.

Mikrokapsul ALTJ mengandung campuran karbohidrat dan protein berupa maltodekstrin dan natrium kaseinat. Maltodekstrin sebagai produk modifikasi pati sedangkan natrium kaseinat merupakan protein susu yang banyak digunakan sebagai pengemulsi, keduanya berperan besar dalam penentuan sifat viskoelastisitas emulsi dari mikrokapsul. Sebagaimana yang dinyatakan Fetouhi et al. (2019) bah- 
wa protein merupakan komponen utama yang bertanggungjawab dalam sifat viskoelastis dalam produk pangan yang berbasis campuran protein dan pati. Penambahan protein dalam komposisinya dengan pati/polisakarida dapat meningkatkan sifat-sifat viskoelastis yang sangat besar pada produk pasta atau gel. ketika protein digabungkan dengan pati atau polisakarida maka akan menyebabkan unit-unit reologi menghasilkan ukuran granula pati yang tidak membesar tetapi 'sel/ikatan' terbentuk oleh benangbenang protein yang diisi oleh granula pati, sehingga membentuk kompleks protein-pati yang padat. Hal inilah yang menyebabkan nilai viskositas emulsi semakin tinggi.

Emulsi yang terlalu kental (viskositas tinggi) dapat menghambat proses penyemprotan pada spray drying karena biasanya terjadi penyumbatan, sehingga sulit untuk di injek ke dalam alat spray dryer. Selain itu, tingginya viskositas emulsi juga dapat menghambat pengeringan pada tabung inlet, akibatnya mikrokapsul yang dihasilkan memiliki kadar air tinggi, akhirnya terjadi clogging (penempelan) pada tabung pengeringan (Yuslinawati, 2014).

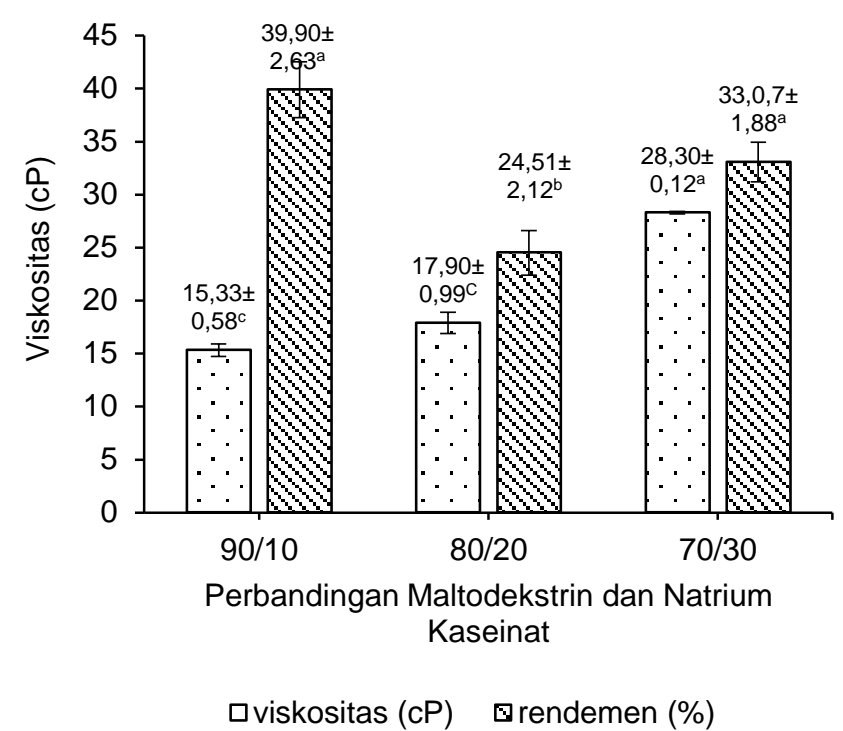

Keterangan: Notasi huruf yang berbeda menunjukkan perbedaan yang signifikan $(P<0,05)$ antar perlakuan. Hasil ini diperoleh dari ketiga perbandingan kombinasi maltodekstrin dan natrium kaseinat dari rataan tiga kali ulangan

Gambar 1. Viskositas emulsi dan rendemen mikrokapsul

Minyak total, minyak tidak terkapsul, efisiensi
mikroenkapsulasi, dan rendemen minyak teren-
kapsulasi

Kombinasi perbandingan antara maltodekstrin dan natrium kaseinat memiliki pengaruh nyata terhadap masing-masing parameter minyak total (MT), minyak tidak terkapsul (MTT), efisiensi mikroenkapsulasi (EM) dan rendemen minyak terenkapsulasi (RMT).

Efisiensi mikroenkapsulasi merupakan parameter yang menunjukkan kemampuan bahan pengapsul dalam menyalut inti, serta tingkat efisiensi proses emulsifikasi dan enkapsulasi (Yuliasari et al., 2016). Parameter ini ditentukan dari nilai minyak total dan minyak tidak terkapsul. Nilai efisiensi yang maksimal diperoleh dari nilai minyak total yang tinggi dan minyak tidak terkapsul yang rendah. Nilai minyak total yang tinggi tidak akan menghasilkan efisiensi yang tinggi apabila minyak tidak terkapsulnya juga tinggi. Minyak tidak terkapsul merupakan minyak yang berada pada permukaan dinding mikrokapsul. Minyak ini tidak diinginkan kehadirannya karena memilki hubungan dengan stabilitas mikrokapsul selama penyimpanan. Kadar minyak tidak terkapsul yang tinggi memiliki keterkaitan dengan pembentukan off flavor dan rendahnya stabilitas pada mikrokapsul jika terpapar dengan kondisi lingkungan (Kaushik et al., 2014).

Berdasarkan Gambar 2, adanya penambahan konsentrasi natrium kaseinat di dalam emulsi membuat keempat parameter (Minyak total, minyak tidak terkapsul, efisiensi mikroenkapsulasi, dan rendemen minyak terenkapsulasi) mengalami peningkatan secara perlahan. Nilai minyak total berkisar antara 5,14; 7,20; dan 9,82\%. Persentase minyak tidak terkapsul berturut-turut yaitu 2,66; 3,25; dan 3,59\%, sedangkan efisiensi mikroenkapsulasinya berturutturut yaitu 45,15; 54,09; dan 63,08\%. Perbandingan $70 / 30$ menghasilkan nilai efisiensi tertinggi. Hal ini menunjukkan bahwa natrium kaseinat dalam kombinasi penyalut tersebut mampu menyalut bahan isian lebih baik karena sifat emulsifiernya lebih tinggi. Quynh et al. (2016) yang menyatakan dalam penelitiannya, adanya peningkatan rasio maltodekstrin/ natrium kaseinat dari 1/0,2-1/0,6 dapat meningkatkan nilai EM dari 48,05-66\%.

Rendemen minyak terenkapsulasi (RMT) merupakan salah satu parameter keberhasilan mikroenkapsulasi. Nilai RMT menunjukkan besarnya minyak yang terbuang (loss) selama proses mulai saat persiapan bahan pengapsul, emulsifikasi hingga pengeringan. Nilai RMT dipengaruhi oleh minyak total dalam mikrokapsul. Nilai RMT merupakan nilai persentase minyak yang ada pada mikrokapsul baik yang tersalut maupun yang berada pada permukaan dinding, sedangkan nilai MTT hanya meliputi persentase minyak yang ada pada permukaan dinding, sehingga nilai MTT akan lebih kecil dari RMT.

Berdasarkan hasil penelitian (Gambar 2), nilai RMT berturut-turut yaitu 14,67; 12,95; hingga $24,13 \%$. Hal ini dapat diduga bahwa formula terbaik dalam adalah 70/30. Perbandingan 70/30 dapat dikatakan mampu menyelimuti droplet konsentrat ALTJ dalam emulsi karena memiliki kandungan 
natrium kaseinat yang lebih tinggi dibandingkan dengan perbandingan 90/10 dan 80/20. Hal ini menyebabkan kemampuan menyelimuti droplet meningkat sehingga nilai RMT tinggi.

Selain minyak total, jenis minyak dan konsentrasi minyak serta kombinasi penyalut yang digunakan juga memengaruhi nilai RMT. Sehingga nilai RMT sangat bervariasi pada setiap penelitian. Misalnya Quynh et al. (2016) pada mikrokapsul gac oil. Penelitian tersebut menggunakan variasi perbandingan maltodekstrin dan natrium kaseinat yang berkisar antara 1:0,2-1:1. Persentase peningkatan RMT maksimum sebesar $70,31 \%$ perbandingan $1: 0,6$. Selanjutnya nilainya menurun pada perbandingan 1:0,8 dan 1:1. Sedangkan pada Yuslinawati (2014) mengenai mikrokapsul minyak cengkeh, nilai RMT tertinggi yaitu pada kombinasi maltodekstrin/natrium kaseinat (3:1) dengan konsentrasi minyak sebesar $10 \%$ yaitu mencapai $74,52 \%$.

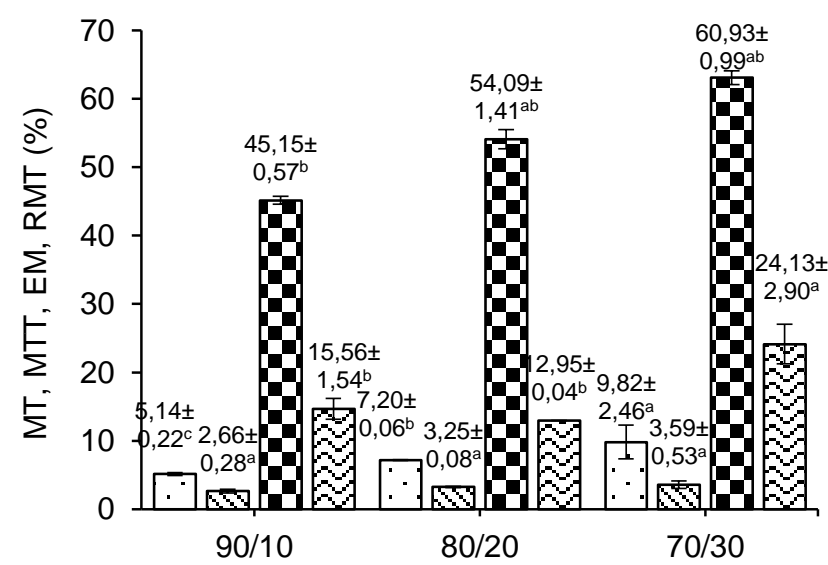

Perbandingan Maltodekstrin dan Natrium Kaseinat

$\square \mathrm{MT} \quad \mathrm{QMTT} \quad \mathbf{E M} \quad \mathbf{R M T}$

Keterangan: Notasi huruf yang berbeda menunjukkan perbedaan yang signifikan $(P<0,05)$ antar perlakuan. Hasil ini diperoleh dari ketiga perbandingan kombinasi maltodekstrin dan natrium kaseinat dari rataan tiga kali ulangan

Gambar 2. Kadar minyak total, minyak tida terkapsul, efisiensi mikroenkapsulasi, dan rendemen minyak tidak terenkapsulasi

\section{Kelarutan dalam air}

Kelarutan dalam air merupakan karakteristik fisik yang diperlukan saat mikrokapsul diaplikasikan ke dalam pengolahan pangan. Berdasarkan data (Gambar 3), kelarutan produk mikrokapsul yang dihasilkan dengan kombinasi maltodekstrin dan natrium kaseinat bernilai tinggi yaitu mencapai $90 \%$. Sedangkan penurunan nilai kelarutan produk mikrokapsul terjadi dengan seiring berkurangnya maltodekstrin dalam campuran bahan penyalut dan me- ningkatnya konsentrasi natrium kaseinat yang digunakan. Hal ini sejalan dengan penelitian Yuliasari et al. (2016) yang mengamati karakteristik mikrokapsul dari minyak sawit merah dengan kombinasi bahan penyalut yang beragam. Hal ini diduga struktur molekul protein pada natrium kaseinat meningkatkan hidrofobisitas mikrokapsul, dan selanjutnya menghambat penyebaran air ke permukaan mikrokapsul (Botrel et al., 2014).

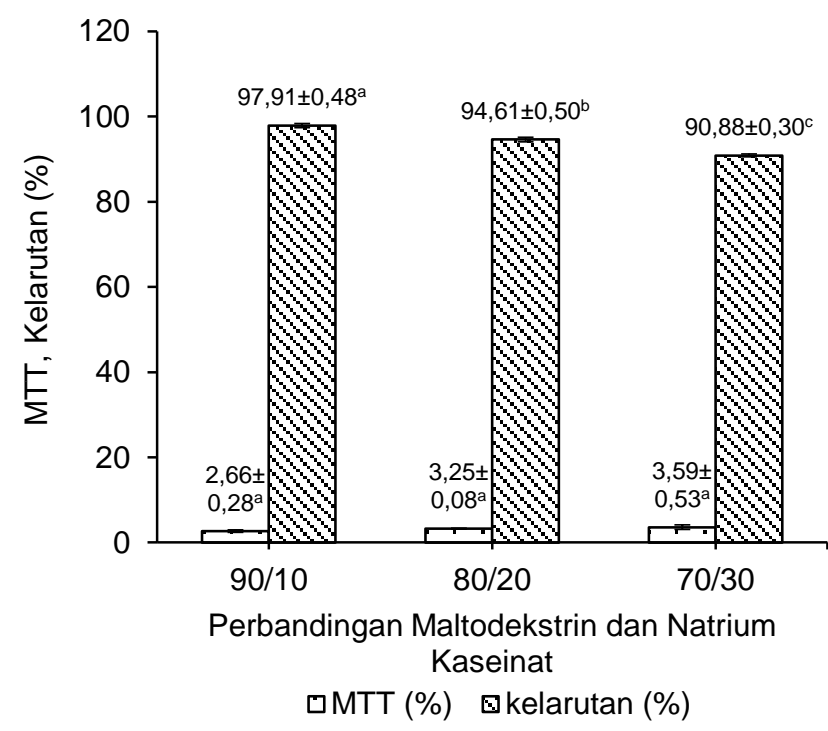

Keterangan: Notasi huruf yang berbeda menunjukkan perbedaan yang signifikan $(P<0,05)$ antar perlakuan. Hasil ini diperoleh dari ketiga perbandingan kombinasi maltodekstrin dan natrium kaseinat dari rataan tiga kali ulangan

Gambar 3. Kadar minyak tidak terkapsul dan kelarutan dalam air

Parameter ini juga berhubungan dengan MTT. Hubungan keduanya berbanding terbalik. Botrel et al. (2014) menyatakan bahwa semakin banyak minyak pada permukaan dinding mikrokapsul maka akan menghambat penyebaran molekul air ke permukaan mikrokapsul. Minyak pada permukaan mikrokapsul tersebut dapat mengubah kondisi lingkungan menjadi lebih hidrofobik. Hal ini menyebabkan produk mikrokapsul sulit larut dan pada akhirnya residu padatan banyak yang tertinggal pada kertas saring.

\section{Karakteristik morfologi}

Citra scanning electron microscope (SEM) merupakan gambaran morfologi permukaan mikrokapsul. Analisis ini dapat menggambarkan karakteristik mikrokapsul seperti keberadaan minyak tidak terkapsul serta laju pelepasan bahan aktif. Berdasarkan Gambar 4 menunjukkan morfologi permukaan mikrokapsul hasil pemotretan oleh instrumen scanning electron microscope (SEM). 


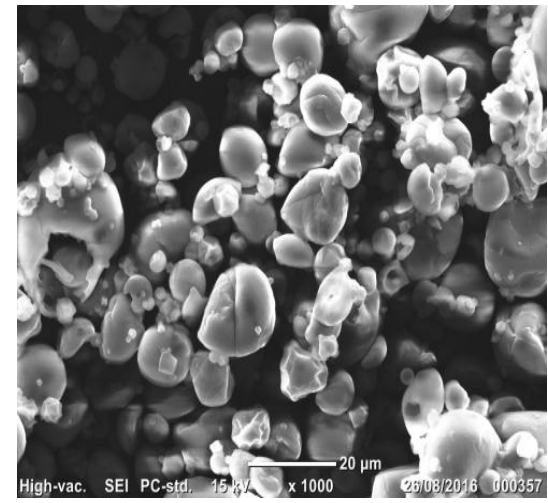

A

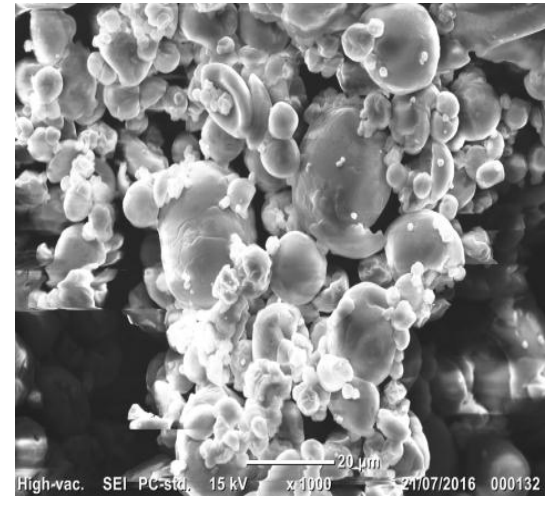

B

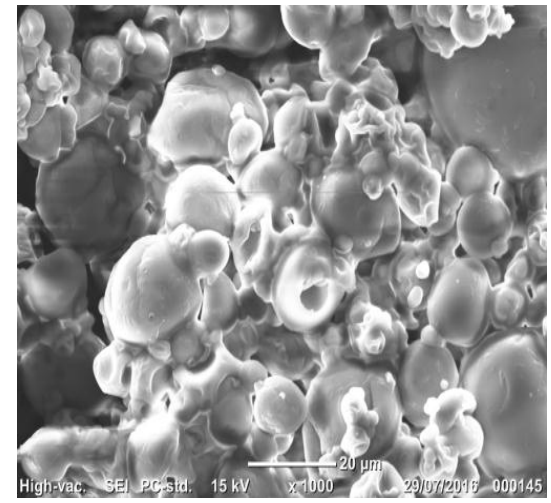

C

Keterangan: Perbandingan 90/10(b/b) (A), 80/20 (b/b) (B), dan 70/30 (b/b) (C) pada perbesaran 100x

\section{Gambar 4. Profil SEM mikrokapsul}

Perbandingan bahan penyalut berupa variasi maltodekstrin dan natrium kaseinat berpengaruh nyata terhadap citra SEM. Mikrokapsul 90/10 (a) menunjukkan sebuah bulatan besar yang dikelilingi bulatan kecil, diduga bulatan kecil merupakan droplet minyak yang tidak terkapsul dimana bentuk bulatan tersebut masih terlihat padat dan kokoh. Mikrokapsul 80/20 (b) tampak adanya beberapa bulatanbulatan kecil yang membentuk kompleks-kompleks tersendiri, selain itu juga tampak adanya sedikit pengempisan. Hal ini diduga karena mikrokapsul tersebut kurang mampu menahan tekanan dari dalam, sehingga dinding mikrokapsul pecah dan terjadi pengempisan. Peristiwa ini disebut ballooning. Yuliasari et al. (2016) menyebutkan bahwa ballooning dapat menyebabkan hilangnya bahan aktif dari mikrokapsul, sehingga minyak tidak terkapsul yang berada pada permukaan dinding mikrokapsul menjadi tinggi. Mikrokapsul 70/30 (c) menunjukkan adanya bentuk mikrokapsul yang melekat satu sama lain, bentuk ini diduga mikrokapsul sudah menggumpal karena tingginya kadar air.

Berbagai macam faktor pada mikroenkapsulasi dapat memengaruhi hasil citra SEM. Peningkatan konsentrasi natrium kaseinat didalam mikrokapsul menyebabkan efisiensi mikroenkapsulasi meningkat karena semakin banyak minyak yang tersalut dan berkurangnya minyak tidak terkapsul. Akan tetapi kondisi ini juga menyebabkan semakin meningkatnya viskositas emulsi yang menyebabkan proses pengeringan semakin sulit. Sedangkan semakin tinggi suhu pengeringan dapat menyebabkan rusaknya bahan aktif. Hal serupa terjadi pada penelitian Yuliasari et al. (2016), ia menyatakan bahwa keretakan dapat disebabkan oleh kekuatan fisik dinding kapsul yang lemah. Diduga kondisi pengeringan $180^{\circ} \mathrm{C}$ telah merusak struktur protein sehingga dinding mikrokapsul dengan bahan penyalut natrium kaseinat mengalami keretakan, pengempisan dan pengerutan, akibatnya sebagian minyak dan bahan aktif keluar dari mikrokapsul, sehingga jumlah minyak tidak terkapsul menjadi tinggi.

\section{Derajat putih}

Derajat putih merupakan parameter warna yang ditampilkan mikrokapsul. Perbandingan bahan penyalut berupa perbandingan maltodekstrin/natrium kaseinat berpengaruh nyata terhadap derajat putih mikrokapsul. Berdasarkan Gambar 5, sampel yang memilki derajat putih paling tinggi yaitu sampel dengan perbandingan 90/10.

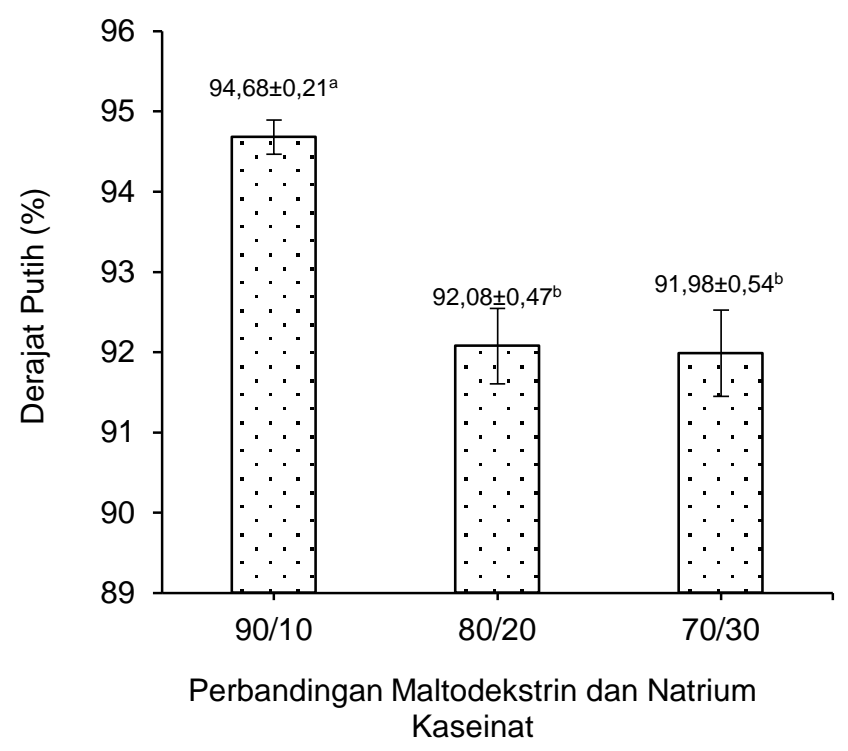

Keterangan: Notasi huruf yang berbeda menunjukkan perbedaan yang signifikan $(P<0,05)$ antar perlakuan. Hasil ini diperoleh dari ketiga perbandingan kombinasi maltodekstrin dan natrium kaseinat dari rataan tiga kali ulangan

Gambar 5. Nilai derajat putih mikrokapsul ALTJ 
Hal ini karena sampel tersebut memiliki konsentrasi maltodekstrin paling tinggi dan natrium kaseinat paling rendah, sehingga warna putihnya dominan. Sedangkan untuk perbandingan $80 / 20$ dan $70 / 30$ menghasilkan nilai derajat putih yang tidak signifikan. Hasil ini serupa dengan pengamatan Pratiwi et al. (2016) pada mikrokapsul minyak esensial dari Cinnamomum burmanii menggunakan bahan penyalut maltodekstrin dan gum arab. Parameter derajat putih ini berguna saat mikrokapsul diaplikasikan ke dalam ingredient produk pangan karena dapat menentukan hasil akhir produk yang dibuat.

\section{KESIMPULAN}

Berdasarkan hasil penelitian, perlakuan kombinasi bahan penyalut berupa maltodekstrin/natrium kaseinat memengaruhi karakteristik mikrokapsul konsentrat ALTJ yang dienkapsulasi dengan maltodekstrin dan natrium kaseinat dengan rasio 90/10, $80 / 20$ dan 70/30. Beberapa kesimpulan yang dapat diperoleh adalah viskositas emulsi konsentrat ALTJ yang dienkapsulasi dengan maltodekstrin dan natrium kaseinat pada berbagai rasio yaitu berkisar 15,33-28,33 cP, rendemen mikrokapsul berkisar antara 24,51-39,89\%, karakteristik mikrokapsul konsentrat ALTJ meliputi kadar minyak total berkisar antara $5,14-9,82 \%$, minyak tidak terkapsul berkisar antara $2,66-3,59 \%$, efisiensi mikroenkapsulasi berkisar $45,15-63,08 \%$, rendemen minyak terenkapsulasi $12,95-24,13 \%$, kelarutan untuk semua formula mencapai $90 \%$, derajat putih tertinggi pada $90 / 10$. Kombinasi maltodekstrin dan natrium kaseinat dengan rasio 70 dan 30 sebagai bahan penyalut dapat melindungi konsentrat asam lemak dengan cukup efektif. Dari ketiga kombinasi tersebut formula yang terbaik adalah 70/30. Kadar rendemen mikrokapsul dan efisiensi mikroenkapsulasi yang tertinggi yaitu sebesar 39,89 dan $63,08 \%$.

\section{UCAPAN TERIMA KASIH}

Penulis mengucapkan banyak terima kasih kepada Balai Besar Riset Pengolahan Produk Bioteknologi Kelautan dan Perikanan (BBRPPBKP) yang telah memberikan dana penelitian dan bekerja sama dalam proyek penelitian ini.

\section{DAFTAR PUSTAKA}

Botrel DA, Fernandez RVD, Borges SV, Yoshida MI. 2014. Influence of wall matrix systems on the properties of spray dried microparticles contain- ing fish oil. Food Res Int 62: 344-352. DOI: 10.1016/j.foodres.2014.02.003.

Carneiro HCF, Tonon RV, Grosso CRF, Hubinger MD. 2013. Encapsulation efficiency and oxidative stability of flaxseed oil microencapsulated by spray drying using different combinations of wall materials. J Food Eng 115: 443-451. DOI: 10.1016/j.jfoodeng.2012.03.033.

Cavallieri ALF, Fialho NAV, Cunha RL. 2011. Sodium caseinate and k-carrageenan interactions in acid gels: Effect of polysaccharide dissolution temperature and sucrose addition. Int $\mathrm{J}$ Food Prop 14: 251-263. DOI: 10.1080/109429109031 76345.

Fetouhi A, Benatallah L, Nawrocka A, Chargot MS, Bouasla A, Mleko MT, Zidoune MS, Sujak A. 2019. Investigation of viscoelastic behaviour of rice-field bean gluten-free dough using the biophysical characterization of proteins and starch: a FT-IR study. J Food Sci Technol 56: 13161327. DOI: 10.1007/s13197-019-03602-2.

Hastarini E, Fardiaz D, Irianto HE, Budijanto S. 2012. Karakteristik minyak ikan dari limbah pengolahan filet ikan patin siam (Pangasius hypopthalmus) dan ikan patin jambal (Pangasius djambal). Agritech 32: 403-410.

Hoiriyah A, Mappiratu, Ridhay A. 2016. Optimalisasi kondisi pemurnian asam lemak tak jenuh dari minyak ikan lele sangkuriang (Clarias batracus) dengan metode kristalisasi urea. Online $\mathrm{J}$ Nat sci 5: 60-68.

[KKP] Kementrian Kelautan dan Perikanan. 2018. Refleksi 2018 \& outlook 2019 Kementrian Kelautan dan Perikanan. https://kkp.go.id/an-com ponent/media/upload-gambar-pendukung/kkp/D ATA\%20KKP/Bahan\%20RO\%20KKP\%202018 \%20(final).pdf [14 Desember 2019].

Kaushik P, Dowling K, Barrow CJ, Adhikari B. 2014. Microencapsulation of omega- 3 fatty acids - a review of microencapsulation and characterization methods. J Funct Foods 19: 868-881. DOI: 10.1016/j.jff.2014.06.029.

Li Y, Hu M, Mc Clements DJ. 2011. Factors affecting lipase digestibility of emulsified lipids using an in vitro digestion model: proposal for standardize $\mathrm{pH}$-stat method. Food Chem 126: 498-505. DOI: 10.1016/j.foodchem.2010.11.027.

Pralea D, Dumitrascu L, Borda D, Stanciuc N. 2011. Functional properties of sodium caseinate hydrolysates as affected by the extent of chymotrypsinolysis. J Agro Proc Technol 17: 308314. 
Pratiwi IY, Darmadji P, Hastuti 2016. Effect of storage temperature on the stability of microencapsulated essential oil from cinnamon (Cinnamomum burmanii). AIP Conference Proceedings 1755: 1-7. DOI: $10.1063 / 1.4958558$.

Quynh NTN, Hai TC, Man PV, Thanh LT. 2016. Effect of wall material on the property of gac oil spray-dried powder. J Nutr Food Sci 6: 1-4. DOI: $10.4172 / 2155-9600.1000544$.

Santos D, Mauricio AC, Sencadas V, Santos JD, Fernandez MH, Gomes PS. 2017. Spray driyng: An overview. Intechopen Chapter 2: 9-35. DOI: 10.5772/intechopen.72247.
Trisnawati AR, Cahyaningrum SE. 2014. Enkapsulasi pirazinamid menggunakan alginat-kitosan dengan variasi konsentrasi surfaktan tween 80 . UNESA J Chem 3: 27-33.

Yuliasari S, Fardiaz D, Andarwulan N, Yuliani S. 2016. Karakteristik enkapsulat minyak sawit merah dengan pengayaan $\beta$-karoten. Informatika Pertanian 25: 107-116. DOI: 10.21082/ip.v25 n1.2016.p107-116.

Yuslinawati. 2014. Formulasi Mikroenkapsulasi Minyak Cengkeh untuk Pestisida Nabati. [Tesis]. Bogor: Fakultas Teknologi Pertanian, Institut Pertanian Bogor. 